\title{
The Ultrastructure of Polyploid B-Cells in the Islets of Normal Mice
}

\author{
R. E. Bowen and F. J. Swartz \\ Dept. of Anatomy, Univ. of Louisville School of Medicine, Health Sciences Center, Louisville, Kentucky, U.S.A.
}

\begin{abstract}
Summary. Light and electron microscopic studies of diploid, tetraploid and octaploid B-cells in the islets of normal C57BL/KsJ mice revealed that polyploid cells were characterized by a wider range of granulated states than diploid B-cells. The maximum granule densities were similar for polyploid and diploid cells; however, some polyploid cells were almost devoid of granules, while the least granulated diploid cells contained intermediate granule densities. The tetraploid cells also appeared to be characterized by an increased mitochondrial stage which suggests compensation for the greater degree of degranulation. These observations were confirmed by morphometric analysis. Two interpretations of the apparent polyploidy are discussed; that polyploid B-cells may be more responsive to insulin releasing stimuli than diploid $B$-cells and that tetraploid cells may only be diploid cells in the $G_{2}$ phase of the mitotic cycle.
\end{abstract}

Key words: Pancreatic islets in mice, genotype: C 57BL/KsJ, ultrastructure, B-cells, nuclear volume classes, polyploidy, DNA replication, morphometric analysis.

Despite suggestions that polyploid cells are functionally differentiated from their diploid counterparts and may be associated with increased synthetic activity or other active metabolic processes [1-4], the precise functional significance of the polyploid state remains obscure. A major problem has been the identification of a polyploid cell system of known function and constant nuclear DNA variation.

With the discovery and characterization of polyploid B-cells in human pancreatic islets by Ehrie and Swartz in 1974, a polyploid system in a cell type of well-defined function was established [5]. In further studies, Ehrie and Swartz have indicated that polyploid B-cells are also characteristic of islets of normal C57BL/KsJ and mutant diabetic C57BL/Ks-db/db mice [6]. They concluded that normal human pancreas is characterized by three DNA states, diploid (2n), tetraploid (4n) and octaploid (8n), and that Bcell nuclei in twelve week $\mathrm{C} 57 \mathrm{BL} / \mathrm{KsJ}$ and $\mathrm{C} 57 \mathrm{BL} / \mathrm{Ks}-\mathrm{db} / \mathrm{db}$ mice also exhibit distinct DNAvolume classes. In addition, they concluded that the nuclear DNA content of the islet B-cell was directly proportional to the volume of its nucleus. In part, these conclusions form the basis for this paper.

The present work was carried out in an attempt to determine whether any significant ultrastructural differences might exist between B-cells with diploid and polyploid nuclei in the islets of Langerhans of normal C57BL/KsJ mice, differences that might suggest functional differentiation with polyploidy.

\section{Materials and Methods}

\section{Animals and Diet}

Three C57BL/KsJ male littermate mice were obtained from the Roscoe B. Jackson Memorial Laboratory, Bar Harbor, Maine, and allowed free access to Purina Laboratory Chow and water. At twelve weeks of age, tail lengths and body weights were recorded and the animals killed by cervical dislocation.

\section{Preparation for Light and Electron Microscopy}

The pancreata were excised, minced into $1 \mathrm{~mm}^{3}$ blocks and fixed in $0.1 \mathrm{M}$ phosphate buffered $4 \%$ glutaraldehyde solution $(\mathrm{pH}=7.3)$ for one and 


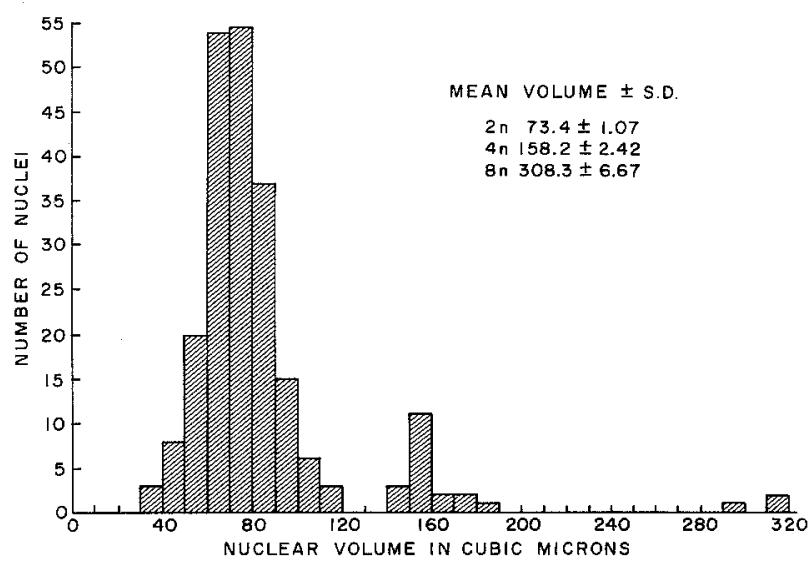

Fig. 1. Maximum mean nuclear volume determinations of pancreatic islet cell nuclei from serial semi-thin and serial thin and adjacent semi-thin sections of islets from three normal 12 week C57BL/KsJ mice

one-half hours [7]. The blocks were than placed in 0.1 $\mathrm{M}$ phosphate buffer $(\mathrm{pH}=7.3$ ) for fifteen minutes and subsequently postfixed in $0.1 \mathrm{M}$ phosphate buffered $1 \%$ OsO4 $(\mathrm{pH}=7.3)$ for two hours [8]. Routine procedures for embedment in Epon 812 [9] were then followed.

\section{Light Microscopy}

One block was selected at random from each of the three mice and semi-thin Epon sections (1.0-1.5 $\mu$ ) were cut on a Porter Blum MT-2 ultramicrotome using a diamond knife. The semi-thin sections were placed on glass slides and islet tissue was identified by staining with hematoxylin and eosin [10], Munger's modification of the aldehyde thionine hematoxylin eosin stain for pancreatic islets embedded in plastic [11], or toluidine blue [12]. Toluidine blue staining proved to be a simple and reliable method for differentiation of islet and acinar tissue, and was employed as the stain of choice for further studies with light microscopy.

Once an islet was identified, serial semi-thin sections were cut. The sections were stained with toluidine blue and subsequently used for nuclear volume class determination. Light micrographs were taken using a high dry apochromatic objective lens $(40: 1$, N.A. $=0.95$ ).

\section{Electron Microscopy}

To permit correlation of nuclear volumes of cells with their location within an islet, sixteen gray to silver sections were cut, followed immediately by a semi-thin section. Six to eight sections were then cut to clear the block face and the process was repeated. The serial thin sections were mounted on 75 mesh copper grids coated with a $0.6 \%$ parlodian solution film, stained with uranyl acetate [13] and lead citrate [14] or lead hydroxide [15] and viewed in a Philips 200 electron microscope. The magnifications of each twelve plate cassette were referenced using a Fullam grid with 54,864 lines per inch.

\section{Determination of Nuclear Volume Classes and of Individual Nuclear Volumes}

Since Ehrie and Swartz determined that, when the $\mathrm{B}$-cell nuclei in the $\mathrm{C} 57 \mathrm{BL} / \mathrm{KsJ}$ mice are treated as spheres, their volumes are directly proportional to their DNA content [6], nuclear volume classes in this study were determined in the same manner. The mean orthogonal diameters of $\mathrm{B}$-cell nuclei in the serial semi-thin, toluidine blue stained, Epon sections were measured with a calibrated filar micrometer. All nuclei in each section were referenced with regard to their postion in the islet and the mean orthogonal diameters of all sections through the same nucleus were ordered. The maximum mean diameter was then used to calculate its nuclear volume. All semi-thin section nuclear volumes were determined using an oil immersion lens $(90: 1$, N.A. $=1.32)$.

For ultrastructural analysis, the mean diameters of the nuclei in contiguous thin sections were ordered with the diameters from the adjacent semi-thin sections. The maximum mean diameter in the ordered set was used to calculate the nuclear volume.

\section{Stereological Methods}

Utilizing the point count technique of Weibel [16], the beta granule and mitochondrial volume densities $\left(V_{v}\right)$ were calculated in two of the three most degranulated diploid cells seen, and in eight diploid and fourteen tetraploid cells selected at random. The average values resulting from morphometric analysis of three to five sections, from each of seven tetraploid cells, indicated that a single section analysis provided granule and mitochondrial volume densities within 2.8 volume per cent of the calculated mean values. The significance between the granule volume densities of the diploid and tetraploid B-cells was determined by the nonparametric Mann-Whitney " $U$ " test [17]. Since insufficient numbers of tetraploids were available, it was not possible to determine if the two tetraploid cells with markedly increased mitochondrial densities (Fig. 5) were statistically significantly different from the remaining cells on the curve. 


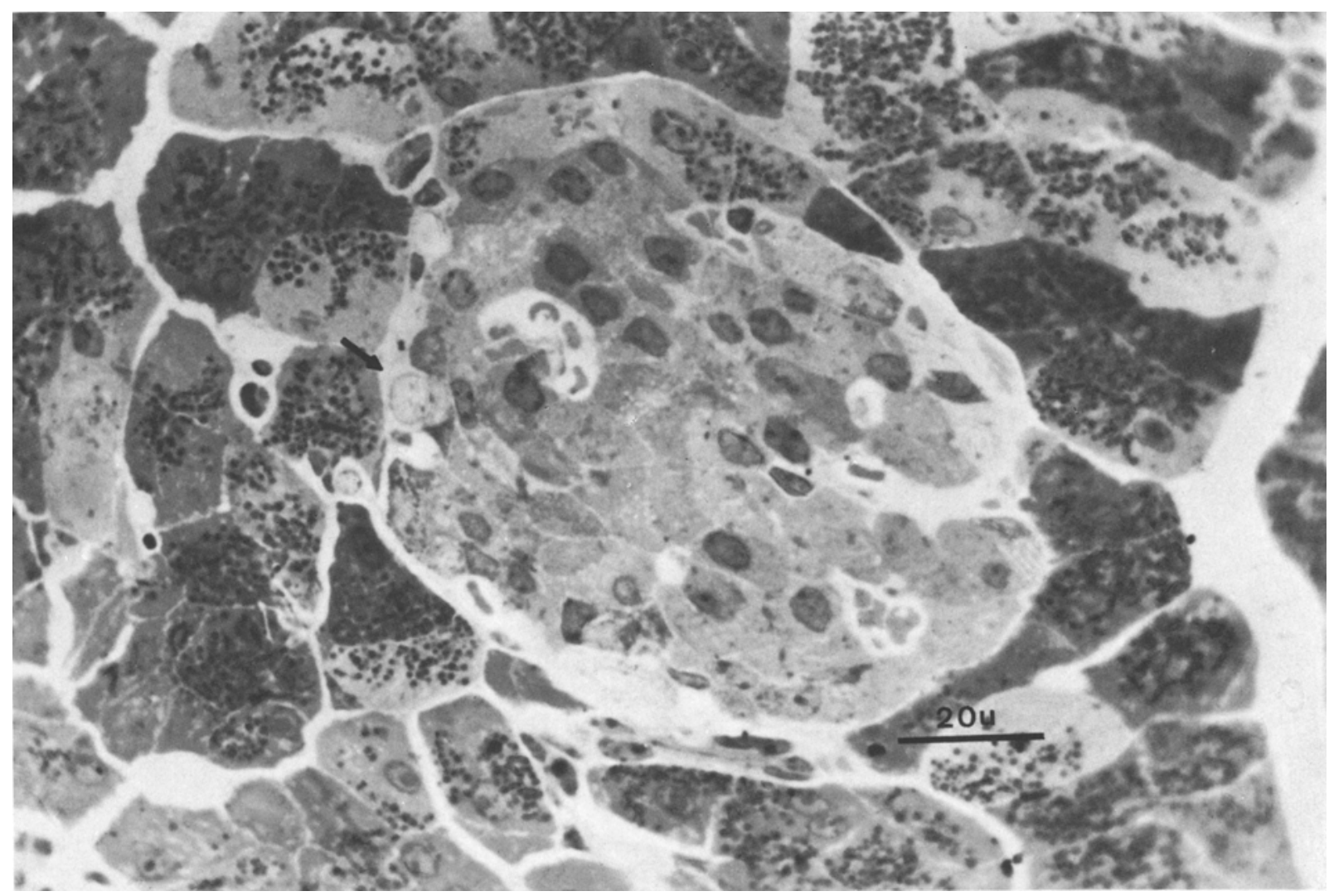

Fig. 2. Section of a pancreatic islet containing a poorly granulated tetraploid B-cell which borders the external islet surface and a capillary (arrow). Toluidine blue

\section{Results}

\section{Animals}

The body weights (24.2-26.3 gms) and tail lengths $(8.1-8.4 \mathrm{cms})$ of the three 12 week C57BL/KsJ mice used in our study compare favorably with those reported previously [6] for $\mathrm{C} 57 \mathrm{BL} / \mathrm{KsJ}$ mice which exhibited distinct B-cell DNA volume classes.

\section{Nuclear Volume Classes}

The distribution of nuclear volumes calculated from the maximum mean diameters of nuclei in the semi-thin series, as well as from the adjacent thin and semi-thin sections, are presented in Figure 1. The mean nuclear volumes for each of the three classes are presented in the upper right hand corner of Figure 1. Nineteen tetraploid and three octaploid nuclei were found in five of the thirteen islets studied. The distribution of polyploid cells in the five islets is shown in Table 1. Tetraploid and octaploid B-cells accounted for $5.2 \%$ and $0.8 \%$, respectively, of the total number of $\mathrm{B}$-cells studied in these five islets. The maximum mean diameters of all nuclei studied in the thirteen islets gave nuclear volumes which fell within the limits of each of the three volume classes.

\section{Light Microscopy}

Light microscopic examination of semi-thin sections revealed considerable variation in islet size, shape and staining characteristics. The mean diameters of the islets ranged from $45 \mu$ to $250 \mu$, while the shapes varied from essentially spherical to prolate spheroids. Most of the islets contained cells with differing degrees of stain density, but a few exhibited a predominantly moderate or dark staining appearance. Figure 2 shows an islet which is characterized by cells of varying stain densities and which contains a lightly staining tetraploid B-cell. Figure 3 illustrates a moderately staining islet which contains two octaploid B-cells. Polyploid cells were found in some moderately and mixed staining islets, but not in uniformly dark staining islets. At the ultrastructural level, the lighter staining cells were seen to reflect a less granulated state than the darker staining cells. In general, polyploid $\mathrm{B}$-cells were located on the external islet surface or 


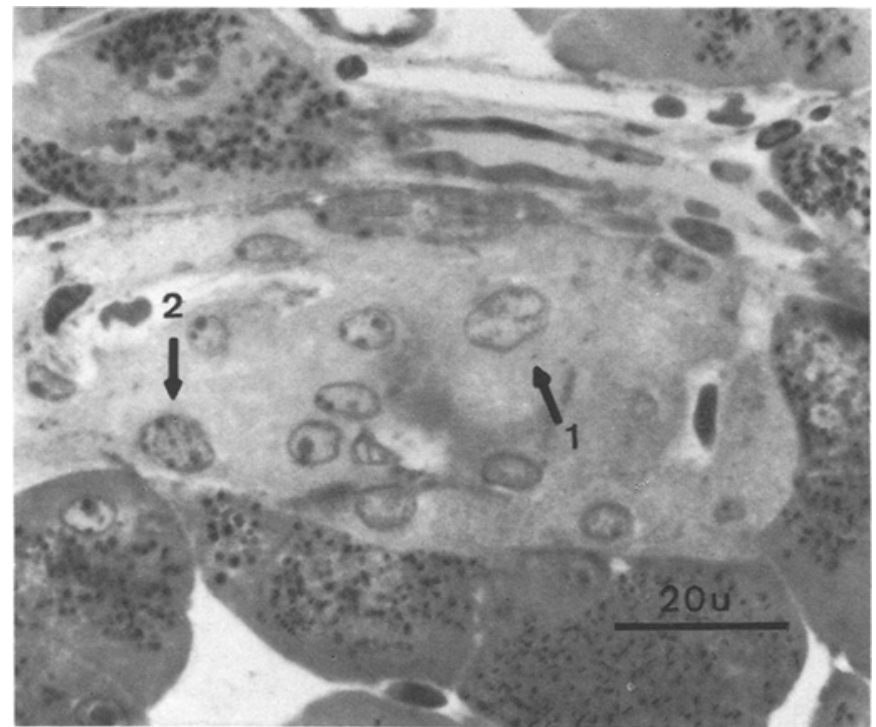

Fig. 3. Section of a pancreatic islet containing two octaploid B-cells; one octaploid ( 1) borders a capillary not seen in this section; the second octaploid (12) lies adjacent to the external islet surface. Toluidine blue
Table 1. Distribution of diploid, tetraploid and octaploid B-cells in the five islets which contained polyploid B-cells

\begin{tabular}{lccll}
\hline Islet & Diploid & Tetraploid & Octaploid & $\%$ Polyploid \\
A & 35 & 2 & 0 & 5.4 \\
B & 63 & 2 & 0 & 3.2 \\
C & 72 & 2 & 0 & 2.7 \\
D & 55 & 0 & 2 & 3.5 \\
E & 116 & 13 & 1 & 10.8 \\
\hline & 341 & 19 & 3 & Mean $=6.0 \%$ \\
\hline
\end{tabular}

adjacent to islet capillaries, while diploid cells were more centrally located in the islet and exhibited no particular spatial relationship to islet capillaries.

\section{Electron Microscopy}

The adjacent thin and semi-thin sections permitted correlation between cell types, nuclear volumes and the location of individual cells within an islet.

1. Diploid $B$-Cells. A study of the diploid cell fine structure revealed differences in granule content (Fig. 4) which were reflected in the stain density using light microscopy (Fig. 4, inset). Morphometric analysis of the diploid cells indicated a minimum granule volume density of $11.2 \%$, a maximum of $30.5 \%$ and a gradation of granule densities between these values (Fig. 5). Most of the diploid cells in the thirteen islets were characterized by granule densities in the upper range.

Ultrastructurally, the mitochondria in diploid cells appeared similar in form, shape and density throughout the range of granulated states; however, morphometric analysis revealed some variation with a moderate increase, of questionable significance, in mitochondrial density of cells with a granule density near $17 \%$ (Fig. 5 ).

A correlation between granule content, cell matrix density and type of ER was seen within the range of diploid granulation. The more degranulated diploid cells were characterized by vesicular or saccular rER and a lighter electron density of the cellular matrix, while the more granulated cells contained lamellar rER and increased electron densities of the cellular matrix (Fig. 4)

2. Tetraploid B-Cells. Although the nineteen tetraploid cells represent only a small percentage of the total number of cells studied, their fine structure revealed a greater range of variation than that seen in the diploid cells. The most obvious differences were a greater degree of degranulation and a stage of increased mitochondrial content.

Fourteen tetraploids were analyzed morphometrically with regard to their granule and mitochondrial volume densities (Fig. 5). The data revealed a minimal granule density of $0.5 \%$ and a gradation of granule densities up to a maximum of $30.6 \%$. Six of the fourteen tetraploids exhibited granule densities less than the least granulated of the diploid B-cells. Figure 6 illustrates one example of a degranulated tetraploid B-cell. Morphometric analysis of five sections from this cell indicated an average granule volume density of $3.7 \%$ and an average mitochondrial volume density of $4.4 \%$. The cytoplasm contained small numbers of distinct beta granules, many vesicles studded with ribosomes and compact groups of microvesicles. The cytoplasmic content of vesicular rER was most pronounced in tetraploid cells with low granule densities; 


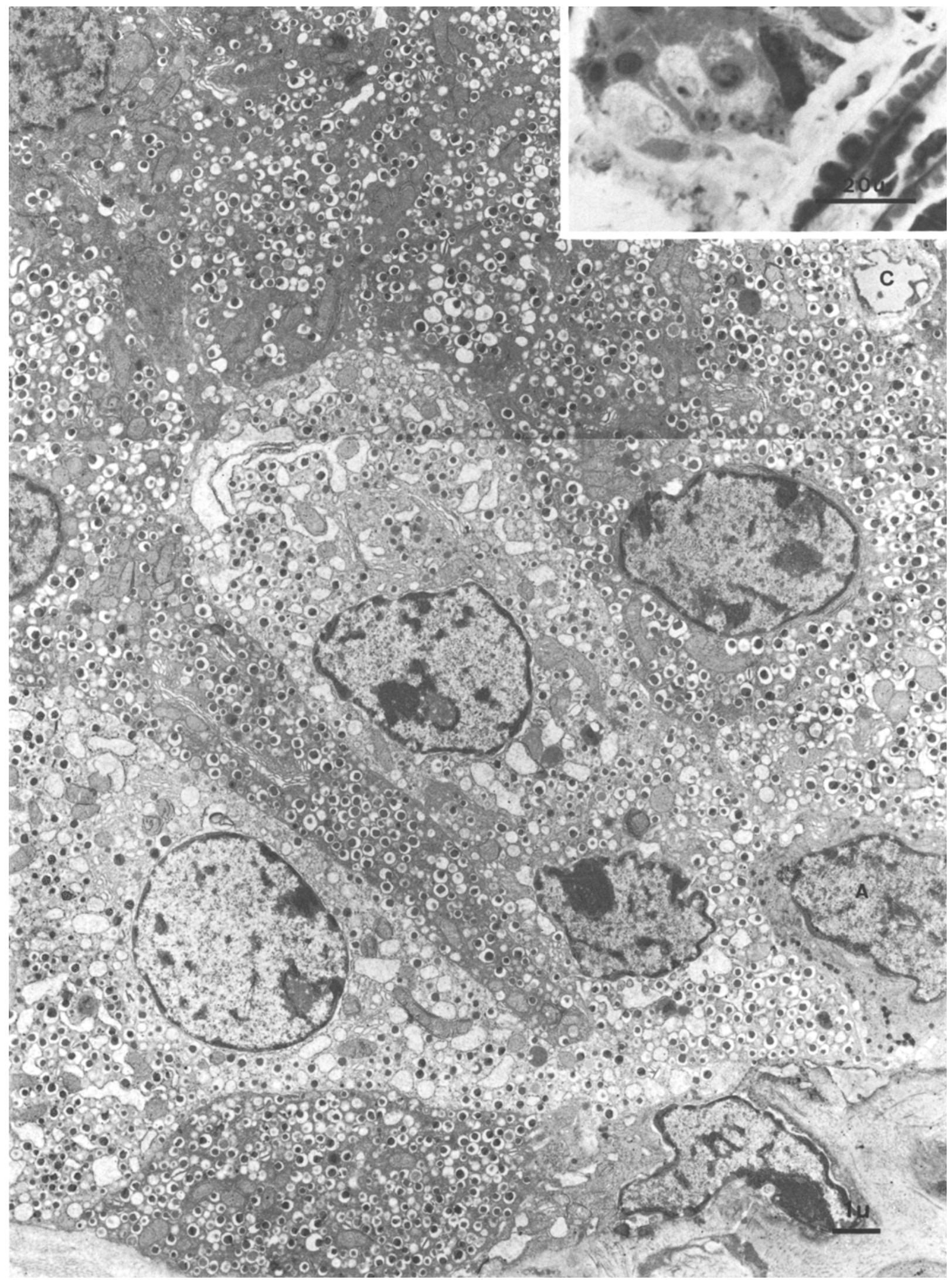

Fig. 4. An electron micrographic collage of a portion of a pancreatic islet which illustrates the range of granulated states characteristic of diploid B-cells. $\mathrm{A}=\mathrm{A}$-cell, $\mathrm{C}=$ capillary. Inset: adjacent semi-thin section showing the stain densities, which reflect granule content, and the location of the cells within the islet. Toluidine blue 

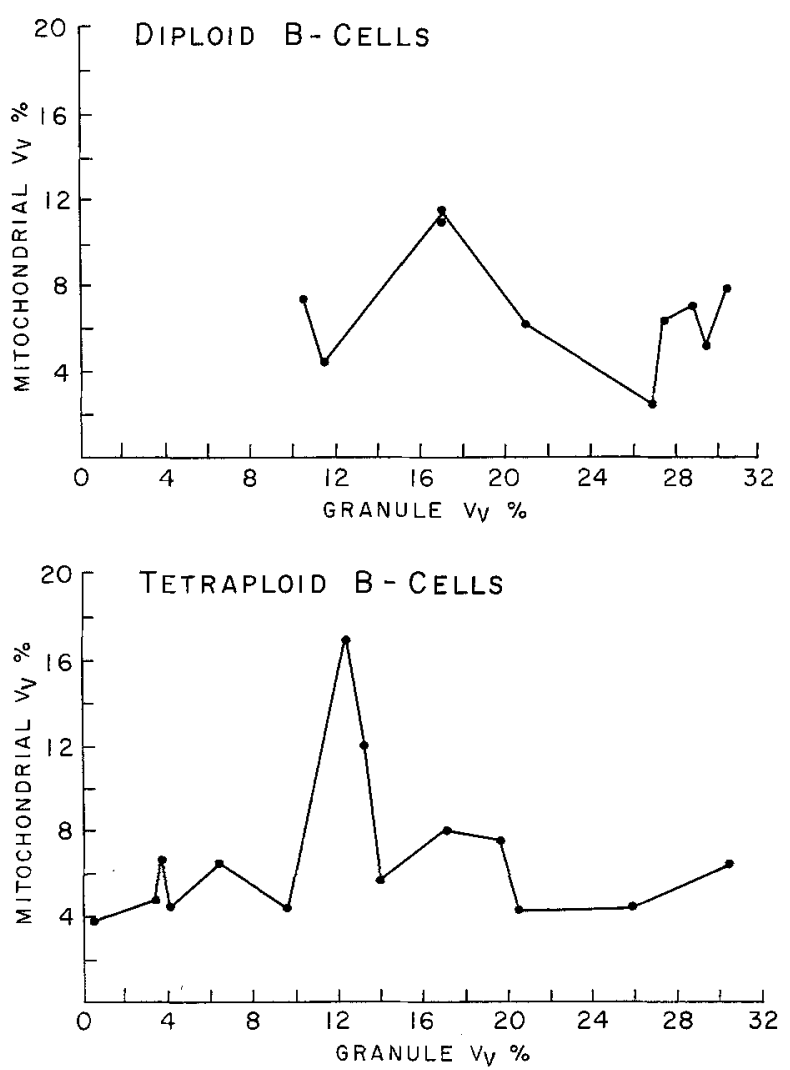

Fig. 5. Granule and mitochondrial volume densities (\%) of diploid and tetraploid B-cells. Each point represents one cell

as the granule content increased, the vesicular rER component decreased and was eventually replaced, at higher granule densities, by lamellar rER.

In observing the number and shape of mitochondria as a function of granule content, an interesting phenomenon was noted. The mitochondrial density in tetraploid B-cells appeared relatively constant; however, a marked increase was seen between granule densities of $11 \%$ and $14 \%$ (Fig. 5). Two of the nineteen tetraploid cells, both containing granule densities near $12 \%$, were characterized by extensive networks of mitochondria which appeared in a variety of elongate, branched or curved forms. No diploid cells containing as distinctive a cytoplasmic mitochondrial component were ever seen. Figure 7 illustrates the appearance of the mitochondria in one of these cells. The average granule and mitochondrial densities ( $\mathrm{n}=$ 3 ) of this cell were $12.4 \%$ and $16.9 \%$, respectively. The beta granule content was increased considerably over that in Figure 6 and free ribosomes were seen in the cytoplasm. A close relationship of this cell to both a capillary and the external islet surface was seen in the adjacent semi-thin section (Fig. 7, inset).

As the granule content increased beyond the stage of increased mitochondrial density, the fine structural characteristics of the tetraploid cells merged with the ultrastructural characteristics of the diploid cells. Except for distinct nuclear volumes, the more highly granulated diploid and tetraploid cells could not be differentiated.

Like the diploid B-cells, a correlation between granule content, type of ER and cellular electron density was apparent in the tetraploid B-cells.

3. Octaploid B-Cells. Due to the limited number of octaploid B-cells encountered, no attempt was made to order them according to their granule and mitochondrial content. However, all three octaploid cells could be placed within the limits of the granule densities characteristic of the tetraploid cells. The two octaploid cells in Figure 3 were ultrastructurally indistinguishable from the surrounding diploid cells characterized by similar granule densities. The third octaploid cell was characterized by marginated beta granules, vesicular rER, increased mitochondrial branching and increased cellular length (approx. $33 \mu$ ). On the basis of its ultrastructure, the third octaploid cell was comparable to the more degranulated tetraploid B-cells.

\section{Discussion}

The B-cell nuclear volume classes presented in Figure 1 exhibited ratios closely approximating $1: 2: 4$, and correspond to the nuclear volume class ratios reported by Ehrie and Swartz in their Feulgen microdensitometric studies of 12 week C57BL/KsJ and C57BL/Ks-db/db mice [6]. The $17 \%, 19 \%$ and $21 \%$ increases in mean nuclear diameter over those previously reported most likely indicate a difference between islets fixed with Zenker-formol and embedded in paraffin and those fixed with glutaraldehyde-OsO $\mathrm{O}_{4}$ and embedded in Epon 812. In general, these consequences of fixation at the light and electron microscopic levels are well known. The consistency of the increase in mean nuclear diameters and the similarity of the nuclear volume distribution curves, indicate that the volume classes in this study reflect accurately the diploid, tetraploid and octaploid values of DNA characteristic of the volume classes reported by Ehrie and Swartz.

As indicated in the results section, a correlation between electron density and form of endoplasmic reticulum with granule density was found. These may represent artifacts of fixation since previous $\mathrm{EM}$ studies on pancreatic islet tissue from $\mathrm{C} 57 \mathrm{BL} / \mathrm{KsJ}$ mice fixed by perfusion revealed no correlation between these characters and the granule content [18].

Although the relatively small number of polyploid cells studied may not reflect accurately the full range 


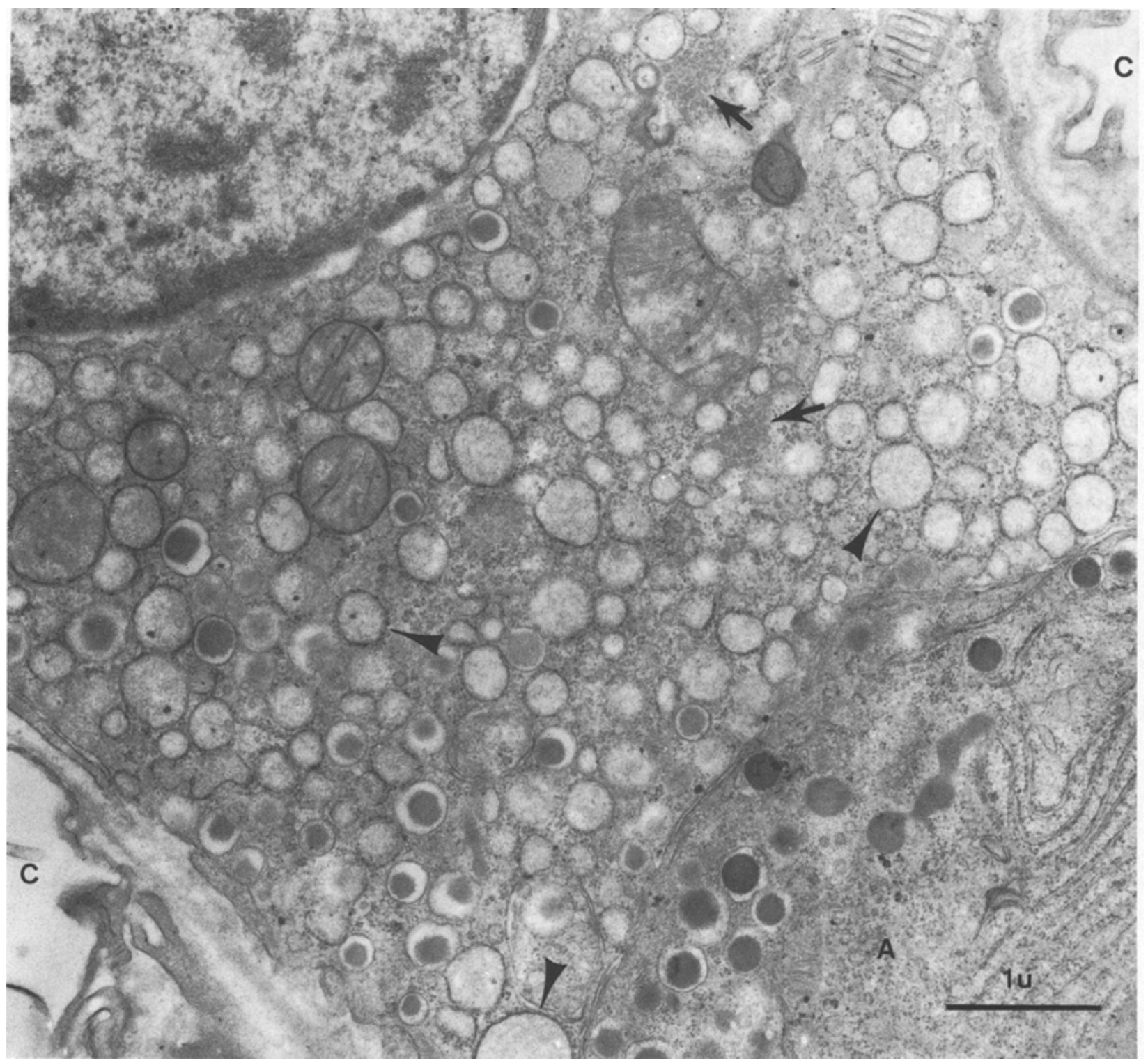

Fig. 6. Portion of a poorly granulated tetraploid B-cell which contains numerous profiles of mitochondria, free cytoplasmic ribosomes and intranuclear filaments (pointer)

or degree of cellular variation characteristic of polyploid cells, it is nevertheless evident that they exhibit a greater range of granulated states than do diploid B-cells. Notably, this is due, not to differences in maximal granule volume densities, but to significantly lower granule densities among the tetraploid cells $(\mathrm{Z}<0.02)$. The presence of two tetraploid cells exhibiting a dramatically increased mitochondrial compartment (Fig. 7) and containing similar granule densities (Fig. 5) suggests, but does not prove, that the greater degree of tetraploid degranulation may be compensated for by an increased potential for energy production related to granule synthesis. Clearly, further studies focussing on tetraploid granule densities approximating $12 \%$ are necessary before an increased mitochondrial stage in tetraploid cells can be confirmed.

The observations that tetraploid cells usually border either the external islet surface or islet capillaries and, ultrastructurally, appear to be normal, active cells, suggest that polyploid cells constitute a cell line which is apparently more responsive to normal stimulation than diploid cells, having the capacity to degranulate completely under conditions which induce only partial degranulation of diploid B-cells. This interpretation is in agreement with other studies 

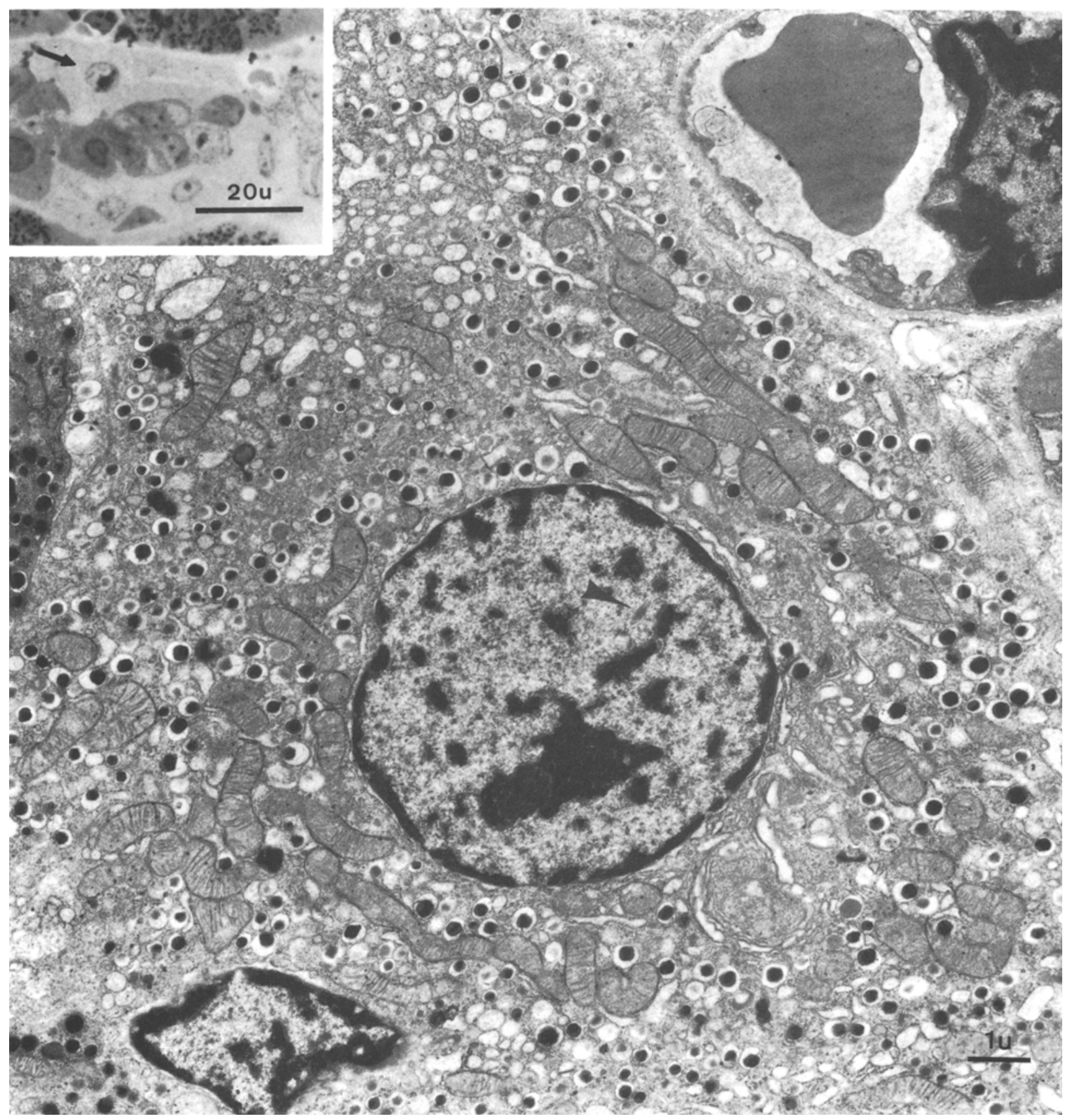

Fig. 7. Micrograph of a partially granulated tetraploid B-cell which contains numerous mitochondria, free cytoplasmic ribosomes and intranuclear filaments (pointer). Inset: Adjacent semi-thin section. The tetraploid cell (arrow) borders the external islet surface and a capillary. Toluidine blue

on localized tissue polyploidy, which suggest that polyploid cells are associated with increased efficiency and metabolic processes [19-21]. If this interpretation is correct, a morphologic basis may exist for the welldocumented biphasic release of insulin [22-27]. The existence of small numbers of apparently more responsive polyploid cells in close proximity to islet capillaries suggests the possibility that the first phase of insulin release may reflect, in part, the differential release of insulin from polyploid B-cells, while the second phase reflects the slower release of insulin from larger numbers of diploid cells.

It is interesting to note that Boquist et al., in studying $\mathrm{C} 57 \mathrm{BL} / \mathrm{KsJ}-\mathrm{db} / \mathrm{db}$ and $\mathrm{C} 57 \mathrm{BL} / 6 \mathrm{~J}-\mathrm{db} / \mathrm{db}$ diabetic mice, described hypertrophic B-cells characterized by large nuclei, prominent Golgi complex and endoplas- 
mic reticulum. The authors suggest that these cells "may reflect a compensatory hyperfunction of the endocrine pancreas in response to hyperglycemia of unknown genesis" [28].

Although we have assumed that the DNA-volume classes reflect a true polyploidy of B-cells, an alternative explanation may be based on studies showing that some DNA replication occurs under normal physiological conditions [29-33], and that at least some of the DNA replication reflects preparation for mitotic division [34-37]. The interpretation that DNA replication in B-cells represents only preparation for cell division, suggests the possibility that cells with multiple DNA classes may only be diploids in the $\mathrm{G}_{2}$ phase of their mitotic cycle.

There are, however, several problems inherent in this interpretation. First, if it is assumed that "tetraploid" cells are merely diploid cells in $\mathrm{G}_{2}$, it becomes difficult to explain the "octaploid" B-cells seen in this study and in others $[5,6]$. On this basis, an "octaploid" cell must be the $G_{2}$ stage of a non-existent "tetraploid" cell. Secondly, we are unaware of studies that would support the existence of as wide a range of cytological variation during $G_{2}$ as have been observed among the tetraploid cells in this study. Furthermore, Like and Chick have observed that "there are very few labelled cells among the islets of normal mice (C57BL/KsJ) at all ages (4-28 weeks) examined. In most instances a random section of the entire pancreas contains a total of not more that 5 labelled ( $\mathrm{H}^{3}$-thymidine) islet cells" [38]. These observations are of interest because our preliminary studies indicate that 4 week C57BL/KsJ mice contain fewer, and 16 week mice more, polyploid cells than 12 week mice (R. E. Bowen and F. J. Swartz, unpublished results). This suggests that the mitotic rate may not correlate with increased polyploidy. It is also interesting to note that in an ultrastructural study of monolayer islet cultures incubated at high glucose concentrations (16.5 $\mathrm{mM}$ ), three classes of epithelioid cells containing small, medium and large nuclei were described [37]. The size of the nuclei correlated inversely with the degree of aldehyde-thionine staining. If it can be assumed that the three nuclear classes observed correspond to the three polyploid classes reported in these studies, and that the degree of aldehyde-thionine staining is related to the granule volume density, then the increased amount of insulin released into the culture medium in response to high glucose levels would be consistent with the interpretation that polyploid B-cells are more responsive to stimulation than are diploid cells. Lastly, the close anatomical and embryological relationship of the pancreas to the liver, in which the existence and development of polyploidy has been documented [39], is further indirect support for the interpretation that true polyploidy may exist in pancreatic islets.

Clearly, the problem of whether some B-cells are polyploid cells characterized by a greater response to normal stimulation or diploid cells in $\mathrm{G}_{2}$ remains to be resolved. However, until chromosome counts are made and the mitotic indices can be correlated with numbers of polyploid cells, results derived from B-cell DNA labelling studies should be interpreted, at least in part, as a reflection of polyploidization. The observation that tetraploid and octaploid cells can be less granulated than the most degranulated diploid cells, under identical physiological conditions, suggests that at least some polyploid cells may be more responsive to insulin release stimuli than diploid B-cells.

Acknowledgements. This study was supported by USPHS General Research Support Grant. The paper was submitted by the senior author in partial fulfillment of the requirements for the degree of Master of Science at the University of Louisville. We gratefully extend our appreciation to Dr. Arthur A. Like and to Dr. Michael G. Ehrie (Peter Bent Brigham Hospital, Boston) for their time, interest and comments on our work.

\section{References}

1. Huskins, C. L., Steinitz, L. M.: The nucleus in differentiation and development. J. Hered. 39, 35-43 (1948)

2. Eagle, H.: Metabolic controls in cultured mammalian cells. Science 148, 42-51 (1965)

3. Lapham, L. W., Johnston, M. A.: Cytologic and cytochemical studies of neuroglia: II. The occurrence of two DNA classes among glial nuclei in the Purkinje cell layer of normal adult human cerebellar cortex. Arch. Neurol. (Chic.) 9, 194-202 (1963)

4. Wagner, D., Richart, R., Temer, J.: DNA content of human endometrial gland cells during the menstrual cycle. Amer. J. Obstet. Gynec. 100, 90-97 (1968)

5. Ehrie, M. G., Swartz, F. J.: Diploid, tetraploid and octaploid B-cells in the islets of Langerhans of the normal human pancreas. Diabetes 23, 583-588 (1974)

6. Ehrie, M. G., Swartz, F. J.: Polyploidy in the pancreas of the normal and diabetic mutant mouse. Diabetologia 12, 167-170 (1976)

7. Sabatini, D. D., Bensch, K., Barrnett, R. J.: Cytochemistry and electron microscopy: The preservation of cellular ultrastructural and enzymatic activity by aldehyde fixation. J. Cell Biol. 17, 19-58 (1963)

8. Millonig, G.: Further observations on a phosphate buffer for osmium solutions in fixation. In: Electron microscopy, Vol. 2 (ed. S. S. Bresse), p. 8. (Fifth International Congress for Electron Microscopy, Philadelphia, Pennsylvania, 1962) New York and London: Academic Press 1962

9. Luft, J. H.: Improvements in epoxy embedding methods. J. biophys. biochem. Cytol. 9, 409-414 (1961)

10. Pool, C. R.: Hematoxylin-eosin staining of $\mathrm{OsO}_{4}$-fixed epon embedded tissue; prestaining oxidation by acidified $\mathrm{H}_{2} \mathrm{O}_{2}$. Stain Technol. 44, 75-79 (1969) 
11. Munger, B. L.: Staining methods applicable to sections of osmium-fixed tissue for light microscopy. J. biophys. biochem. Cytol. 11, 502-506 (1961)

12. Trump, B. F., Smuckler, E. A., Benditt, E. P.: A method for staining epoxy sections for light microscopy. J. Ultrastruct. Res. 5, 343-348 (1961)

13. Watson, M. L.: Staining of tissue sections for electron microscopy with heavy metals. J. biophys. biochem. Cytol. 4, 475-478 (1958)

14. Reynolds, E. S.: The use of lead citrate at high $\mathrm{pH}$ as an electronopaque stain in electron microscopy. J. Cell Biol. 17, 208-212 (1963)

15. Karnovsky, M. J.: Simple methods for staining with lead at high $\mathrm{pH}$ in electron microscopy. J. biophys. biochem. Cytol. 11, 729-732 (1961)

16. Weibel, E. R.: Stereological principles for morphometry in electron microscope cytology. Int. Rev. Cytol. 26, 235-303 (1969)

17. Siegel, S.: Nonparametric statistics for the behavioral sciences. pp. 116-127. New York: McGraw-Hill Book Company, Inc. 1956

18. Like, A. A., Chick, W. L.: Studies in the diabetic mutant mouse: II. Electron microscopy of pancreatic islets. Diabetologia 6, 216-242 (1970)

19. Kompmann, M., Paddags, I., Sandritter, W.: Feulgen cytophotometric DNA determination on human hearts. Arch. Path. 82, 303-308 (1966)

20. Painter, T. S., Biesele, J. J.: Endomitosis and polyribosome formation. Proc. Nat. Acad. Sci. (Wash.) 56, 1920-1925 (1966)

21. Floyd, A. D., Swartz, F. J.: The uterine epithelium of Ascaris lumbricoides as a model system for the study of polyploidy. Exp. Cell Res. 56, 275-280 (1969)

22. Grodsky, G. M., Bennett, L. L., Smith, D. F., Schmid, F. G.: Effects of pulse administration of glucose or glucagon on insulin secretion in vitro. Metabolism 16, 222-233 (1967)

23. Grodsky, G. M., Bennett, L. L., Smith, D., Nemechek, K.: The effect of tolbutamide and glucose on the timed release of insulin from the isolated perfused pancreas. In: Tolbutamide . . . after ten years (eds. W. J. H. Butterfield, W. van Westering), Excerpta Medica Found. Int. Congress Series (Amst.) No. 149, 11-21 (1967)

24. Pfeiffer, E. F.: Dynamics of insulin secretion in normal, obese and diabetic subjects following B-cell stimulation. In: Tolbutamide ... after ten years (eds. W. J. H. Butterfield, W. van Westering), Excerpta Medica Found. Int. Congress Series (Amst.) No. 149, 127-139 (1967)

25. Grodsky, G., Landahl, H., Curry, D., Bennett, L.: In vitro studies suggesting a two-compartment model for insulin secretion. In: The structure and metabolism of the pancreatic islets (eds. S. Falkmer, B. Hellman, I. B. Täljedal), Wenner-Gren Symposium 16, 409-421 (1969), Oxford and New York: Pergamon Press 1970

26. Sandgraf, R., Kotler-Grajtburg, J., Matschinsky, F, M.: Kinetics of insulin release from the perfused rat pancreas caused by glucose, glucosamine, and galactose. Proc. Nat. Acad. Sci. (Wash.) 63, 536-540 (1971)

27. Grodsky, G. M.: A threshold distribution hypothesis for packet storage of insulin. II. Effect of calcium. Diabetes 21 (Suppl. 2), 584-593 (1972)

28. Boquist, L., Hellman, B., Lernmark, A., Täljedal, I.-B.: Influence of the mutation "diabetes" on insulin release and islet morphology in mice of different genetic backgrounds. J. Cell Biol. 62, 77-89 (1974)

29. Logothetopoulos, J., Bell, E. G.: Histological and autoradiographic studies of the islets of mice injected with insulin antibody. Diabetes 15, 205-211 (1966)

30. Chick, W. L.: Beta-cell proliferation and DNA synthesis in diabetic mutant mice. Fed. proc. 28, 574 (1969)

31. Chick, W. L., Like, A. A.: Studies in the diabetic mutant mouse: III. Physiological factors associated with alterations in beta-cell proliferation. Diabetologia 6, 243-251 (1970)

32. Chick, W. L.: Beta-cell replication in rat pancreatic monolayer cultures: Effects of glucose, tolbutamide, glucocorticoid, growth hormone and glucagon. Diabetes 22, 687-693 (1973)

33. Andersson, A.: Synthesis of DNA in isolated pancreatic islets maintained in tissue culture. Endocrinology 96, 1051-1054 (1975)

34. Like, A. A., Chick, W. L.: Mitotic division in pancreatic betacells. Science 163, 941-943 (1969)

35. Lambert, A. E., Blondel, B., Kanazawa, Y., Orci, L., Renold, A. E.: Monolayer cell culture of neonatal rat pancreas; light microscopy and evidence for immunoreactive insulin synthesis and release. Endocrinology 90, 239-248 (1972)

36. Chick, W. L., Lauris, V., Flewelling, J. H., Andrews, K. A., Woodruff, J. M.: Effects of glucose on beta-cells in pancreatic monolayer cultures. Endocrinology 92, 212-218 (1973)

37. Orci, L., Like, A. A., Amherdt, M., Blondel, B. Kanazawa, Y., Marliss, E. B., Lambert, A. E., Wollheim, C. B., Renold, A. E.: Monolayer cell culture of neonatal rat pancreas: An ultrastructural and biochemical study of functioning endocrine cells. J. Ultrastruct. Res. 43, 270-297 (1973)

38. Like, A. A., Chick, W. L.: Studies in the diabetic mutant mouse: I. Light microscopy and radioautography of pancreatic islets. Diabetologia 6, 207-215 (1970)

39. Swartz, F. J.: The development in the human liver of multiple desoxyribose nucleic acid (DNA) classes and their relationship to the age of the individual. Chromosoma (Berl.) 8, 53-72 (1956)

Received: August 25, 1975, and in revised form: February 11, 1976

Dr. F. J. Swartz

Univ. of Louisville School of Medicine

Dept. of Anatomy

Health Sciences Center

P. O. Box 1055

Louisville, Kentucky 40201

USA 